\title{
Improved USGS Methodology for Assessing Continuous Petroleum Resources
}

Data Series 547 



\section{Improved USGS Methodology for Assessing Continuous Petroleum Resources}

By Ronald R. Charpentier and Troy A. Cook

Version 2

Data Series 547

U.S. Department of the Interior

U.S. Geological Survey 


\title{
U.S. Department of the Interior \\ KEN SALAZAR, Secretary \\ U.S. Geological Survey \\ Marcia K. McNutt, Director
}

U.S. Geological Survey, Reston, Virginia: 2010

Revised 2012

\begin{abstract}
For more information on the USGS - the Federal source for science about the Earth, its natural and living resources, natural hazards, and the environment, visit http://www.usgs.gov or call 1-888-ASK-USGS

For an overview of USGS information products, including maps, imagery, and publications, visit http://www.usgs.gov/pubprod

To order this and other USGS information products, visit http://store.usgs.gov
\end{abstract}

Any use of trade, product, or firm names is for descriptive purposes only and does not imply endorsement by the U.S. Government.

Although this report is in the public domain, permission must be secured from the individual copyright owners to reproduce any copyrighted materials contained within this report.

Suggested citation:

Charpentier, R.R., and Cook, T.A., 2010, Improved USGS methodology for assessing continuous petroleum resources, version 2: U.S. Geological Survey Data Series 547, 22 p. and program. Revised November 2012. 


\section{Contents}

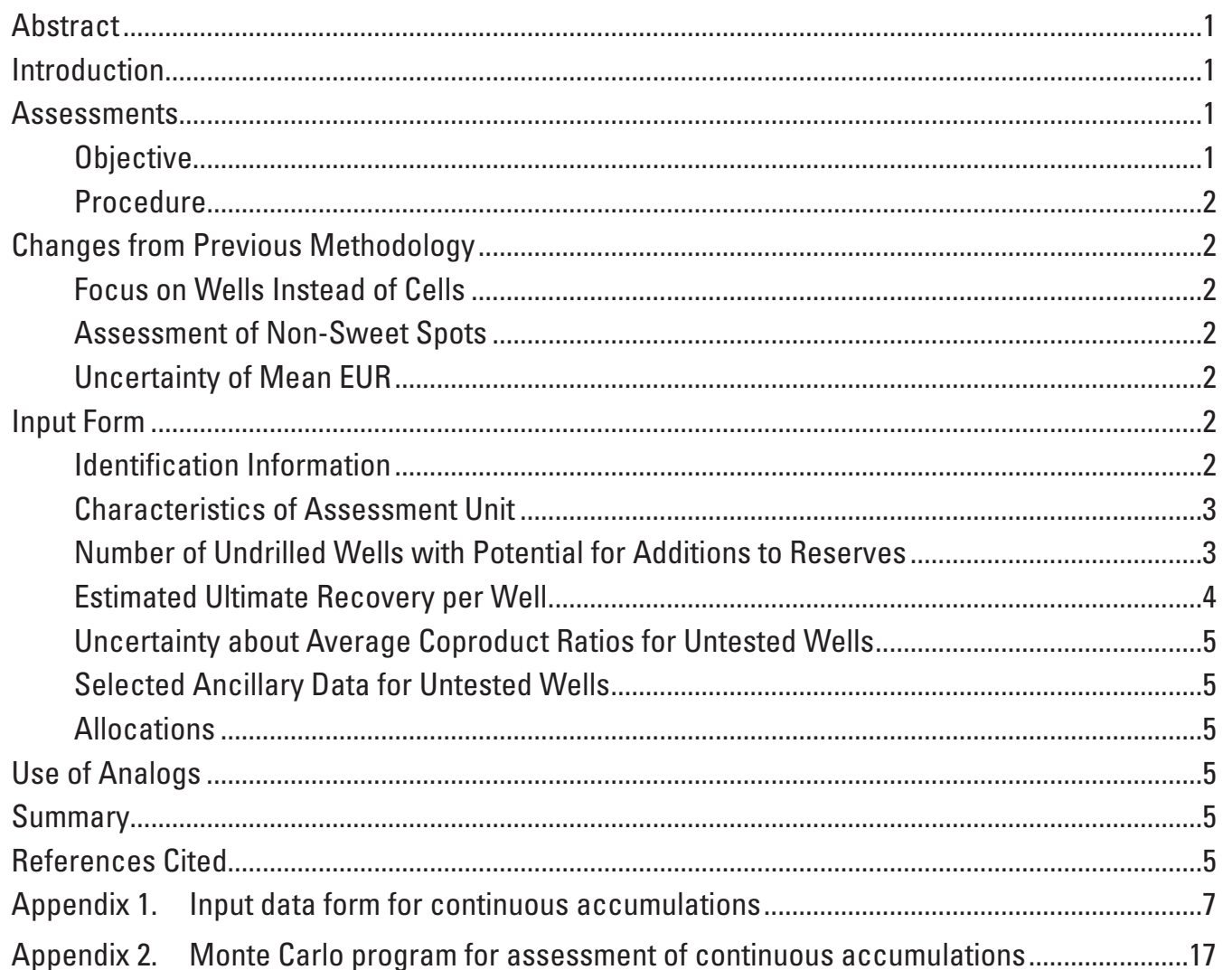





\title{
Improved USGS Methodology for Assessing Continuous Petroleum Resources
}

\author{
By Ronald R. Charpentier and Troy A. Cook
}

\section{Abstract}

This report was originally published in 2010. This edition of the report, version 2, fixes minor bugs relating to correlations and coproducts.

This report presents an improved methodology for estimating volumes of continuous (unconventional) oil and gas resources within the United States and around the world. The methodology is based on previously developed U.S. Geological Survey methodologies that rely on well-scale production data. Improvements were made primarily to how the uncertainty about estimated ultimate recoveries is incorporated in the estimates. This is particularly important when assessing areas with sparse or no production data, because the new methodology allows better use of analog data from areas with significant discovery histories.

\section{Introduction}

The currently used U.S. Geological Survey (USGS) methodology for assessing continuous (unconventional) petroleum resources of the United States was developed in the 1990s and last updated in 2003. Rather than the traditional in-place calculation of resources with a poorly understood recovery factor, the USGS methodology was built to use well-production information to better constrain estimates of recoverable volumes. This was a significant improvement, at least for those resource accumulations that already had significant production history available. As the USGS extends its assessments to hypothetical assessment units (AU) both within and outside the United States (U.S.), the methodology requires improvement to better reflect the greater inherent uncertainties.

The 1990s USGS methodology was based on dividing an AU into cells and assessing the number of untested cells with production potential and the distribution of per-cell production potential. Hundreds to thousands of well production histories were analyzed for each AU to estimate a distribution of wellscale estimated ultimate recoveries (EUR). Cells were scaled to be approximately the average drainage area of a well. The number of potentially productive cells was estimated by dividing the AU area by the well drainage areas. The 2003 version only assesses resources within the areas with higher production potential (sweet spots), rather than the entire AU.
The currently used methodology poorly incorporates uncertainty about the mean of the EUR distribution. This is especially problematic for hypothetical continuous assessment units where this may be the largest source of uncertainty that needs to be reflected in the estimates. The improved methodology estimates the uncertainty of mean EUR directly. It will use analog data to be compiled from production histories of many developed U.S. continuous assessment units. The analog databases will provide a way of estimating the variability of not just EURs but other production parameters useful in assessing continuous resources.

In addition to the analog databases, the improved methodology uses a new Monte Carlo program (Appendix 2) for performing the calculations as well as additional tools to aid assessors in better incorporating the available production data. A series of standard graphs will provide summaries of production data in a probabilistic manner. These graphs will aid interpretation and assessment of both hypothetical assessment units and those with significant production histories.

\section{Assessments}

\section{Objective}

The purpose of this new methodology is to make quantitative, probabilistic estimates of volumes of technically recoverable oil and gas resources from continuous accumulations. A continuous accumulation is "a petroleum accumulation that is pervasive throughout a large area, that is not significantly affected by hydrodynamic influences, and ... lack[s] down-dip water contacts." (Klett, Schmoker, and others, 2003) Examples are gas or oil reservoirs in shales, in low-permeability sandstones and carbonates, and in coals.

The USGS oil and gas estimates are of technically recoverable resources, as opposed to in-place resources. Technologic and economic assumptions are conservative and limited, in that the production data used for calculating well EURs are contemporary to the time of the assessment. Production data, however, have spatial and temporal trends. The intent is to make estimates based on contemporary production practice in the area assessed, or in similar areas. Large improvements in technology or increases in petroleum prices could possibly 
increase recovery factors substantially in the future. Because this new methodology is tied to contemporary well-production data, such improved recovery factors are not used as part of this assessment methodology.

\section{Procedure}

The process of making oil and gas resource assessments begins with geologic studies that attempt, using a petroleum system approach, to explain the controls on oil and gas occurrence in the assessed area. The petroleum system approach examines all of the geologic elements of source, reservoir, seal, and overburden rocks, as well as the processes of generation, migration, entrapment, and preservation of oil, gas, and natural gas liquids. The geologic studies may lead to a division of the area into subunits, either geographically or stratigraphically. The actual volume of rock for which each individual quantitative assessment is made is termed an assessment unit (AU).

After the assessor, or team of assessors, has divided the area into a preliminary set of AUs, production data are retrieved and analyzed for each AU. A geologic review meeting is conducted to present the preliminary geologic interpretations and division into AUs to a review committee consisting of experienced assessors. The geologic interpretations are discussed and the subdivision into AUs is revised if deemed appropriate. After revision, an assessment meeting is held. The assessor presents an input form with preliminary input values for discussion with the review committee. Revisions are made and preliminary results examined. Further revisions to the input are made until the results are a reasonable quantitative reflection of the geologic interpretations. After the assessment meeting, more extensive Monte Carlo simulations are run to calculate the official volume estimates.

\section{Changes from Previous Methodology}

\section{Focus on Wells Instead of Cells}

The first methodology based on well performance (Schmoker, 1995), divided the AU area into cells of constant size. Choice of cell size, however, was based on the expected average drainage area of a well. This would allow the EURs from wells to be used more directly as total recoveries per cell. Later versions (Crovelli, 2000, 2003; Klett and Charpentier, 2003; Klett and Schmoker, 2003; Schmoker, 2003) used a probability distribution for cell sizes based on a distribution of well-drainage areas. The new methodology uses wells directly instead of cells (Appendix 1, page 1). This eliminates the confusion between the two concepts, which were always closely linked. It also reduces the chance of misinterpreting cells as entities that were actually mapped, as opposed to being conceptual.

\section{Assessment of Non-Sweet Spots}

The original USGS methodology based on well performance (Schmoker, 1995) gave estimates for the entire AU. In some cases, this gave very large estimates for numbers of wells and included some resources that were not likely to be relevant to supply for the near future (Schmoker, Fouch, and Charpentier, 1996). A revised methodology (Crovelli, 2000, 2003; Klett and Charpentier, 2003; Klett and Schmoker, 2003; Schmoker, 2003) attempted to solve these problems by dividing the AU into sweet spots and non-sweet spots. The nonsweet spots were considered to be of fairly high risk and low EURs and were not quantitatively assessed.

The new methodology continues to offer the option of dividing the AU into sweet spots and non-sweet spots (Appendix 1, page 2). However, non-sweet spots are now quantitatively assessed in the new methodology. The assessor has the option to treat the area as 100 percent sweet spot if desired. An additional modification is that the future success ratio (probability that a well will have an EUR greater than the minimum size; Appendix 1, page 2) is now explicitly estimated. In the previous version, it had been part of the estimated percent of untested area with potential. The new version requires probability distributions for a future success ratio and for EURs, separately for sweet spots and for nonsweet spots (Appendix 1, page 2).

\section{Uncertainty of Mean EUR}

Because of the large numbers of cells involved in the calculations for an AU (thousands to hundreds of thousands), only the mean of the EUR distribution had any relevance to the volumetric estimates in previous methodologies. This made the methodology inappropriate for AUs that had great uncertainty about the EUR distribution, such as hypothetical or very immature AUs. The improved methodology addresses the uncertainty about EURs directly by means of a probability distribution (Appendix 1, page 2).

\section{Input Form}

The new input form is included as Appendix 1. The input form is the primary record of quantitative input used in the estimation of volumes of technically recoverable oil and gas resources. The input form also includes additional information, termed ancillary data that is not used in the estimation of technically recoverable oil and gas volumes, but describes characteristics of the petroleum that may be of use in further analysis, such as economic analysis.

\section{Identification Information}

The revised input form (Appendix 1) begins with a section labeled "Identification Information." This section identifies 
the AU with the standard USGS hierarchical classification of region, province, total petroleum system, and AU names and codes (Klett, Charpentier, and Le, 2003). The date of the assessment meeting and the responsible geologist(s) are also included. Space is given to identify the data sources, such as databases and analogs used, as well as any general comments.

\section{Characteristics of Assessment Unit}

The next section of the input form entitled, Characteristics of Assessment Unit, starts with three variables used for classification of assessment units (Appendix 1, page 1). The assessment-unit type is identified as either oil or gas, using a 20,000 cubic foot of gas per barrel of oil cutoff. The well type used for undrilled wells in the assessment is identified as vertical or horizontal. This is important because of the large size differences between drainage areas and EURs of vertical versus horizontal wells. The AU is to be estimated as if all future wells were only one of the two types. The AU is then classified as having one of five types of continuous (unconventional) reservoirs: shale, low-permeability clastics, low-permeability carbonates, coal, or diatomite.

Next, the minimum estimated EUR per well is specified in millions of barrels of oil (MMBO) for an oil AU or in billions of cubic feet of gas (BCFG) for a gas AU. Many of the distributions later in the form depend on this specified minimum. Success ratios are defined as the probability of a well having an EUR at least this large. Drainage areas are estimated only for wells at least this large. EUR distributions have this value as their minimum. The minimum is generally kept low, so as to not exclude significant volumes of marginally economic production.

A historic success ratio is calculated on the number of wells that previously tested the accumulation, and the number of those that had an EUR greater than the minimum value. This calculation, unlike other parts of the form, can include both vertical and horizontal wells.

Finally, the AU probability is the probability that the accumulation has at least one well with EUR of minimum size or larger. If wells already exist with EUR greater or equal than the minimum, the AU probability is equal to 1 . Otherwise, the AU probability depends on (1) the existence of the reservoir rock (and the source rock, if separate), and (2) the appropriate thermal (or biogenic) maturation to produce a resource. Reservoirs that are not self-sourced are considered to have little likelihood of significant resources. Thus for shale AUs, the AU probability is the probability of the existence of mature shale with total organic carbon (TOC) of at least 2 weight percent.

\section{Number of Undrilled Wells with Potential for Additions to Reserves}

The next section of the input form includes the input used to calculate the number of undrilled wells in sweet spots and non-sweet spots. For convenience, the important input distributions are identified as lines 1 through 4 .

The uncertainty about the productive area (in acres) of the continuous accumulation is estimated in line 1. Uncertainty in this distribution can come from uncertainty about the areal extent of the reservoir or source rocks (the extent of the organic-rich [ $>2$ percent TOC] portion of the shale, the part of the low-permeability reservoir charged with hydrocarbon, or the areal extent of the coal). The uncertainty can also be related to the part of that reservoir that is thermally or biogenically mature.

The uncertainty about the average drainage area of wells is estimated in line 2. This distribution allows a calculation of number of wells that would be needed to drain a particular area. Because the areas being assessed are large, the numbers of wells involved are in the hundreds to hundreds of thousands. With such a large number of wells, only the mean size of the drainage area is relevant, but uncertainty about that mean is also relevant.

The full per-well distribution of drainage areas is estimated as a shifted truncated lognormal distribution in line 2a. This distribution is not used in the calculation of technically recoverable resources; line 2 is used instead. Line 2a is included as ancillary data that may be helpful to users doing further analysis, such as economic analysis.

The portion of the line 1 area that is untested is estimated by the distribution in line 3 . A rough calculation of the tested portion can be calculated by multiplying the number of tested wells (in "Characteristics of Assessment Unit") by the mean of line 2 and dividing by the mean of line 1.

The critical division of the untested area into two partsthe sweet spots and the non-sweet spots-is estimated in line 4. Non-sweet spots are expected to have significantly lower success ratios and lower EUR distributions. In partially developed AUs, most of the drilling will commonly be in sweet spots. If deemed appropriate to the $\mathrm{AU}$, line 4 can make the AU 100 percent sweet spots and no non-sweet spots. If the geologic understanding of the AU is sufficient to actually map the distribution of sweet spots versus non-sweet spots, it is more appropriate to make those separate AUs. The structure implied in line 4 is that the AU is divided geologically into better and poorer areas that cannot be mapped with certainty given current geological knowledge.

Lines 1 through 4 are all estimated by triangular distributions. Each of the distributions reflects the assessors' uncertainty about a single value that exists in nature but is unknown. The line $2 \mathrm{a}$ distribution, however, represents the distribution of values in a natural population. Greater skewness is needed in this case and thus a shifted truncated lognormal distribution is used.

Most of the geologic information appropriate for estimating the distributions in lines 1 and 4 are best expressed as maps. Therefore, as many of the maps and data sets shown in the following lists should be generated prior to filling out the input form: 
Maps and Data Sets Describing Continuous Accumulations in Shale Reservoirs
Extent of shale reservoir
Thickness of shale reservoir
TOC of shale
Depth of shale reservoir
Thermal maturity
Well data on production and shows
Pressure data
Estimated ultimate recoveries (EURs)

Maps and Data Sets Describing Continuous Accumulations in Low-Permeability Clastic or Carbonate Reservoirs

Extent of low-permeability reservoir

Thickness of low-permeability reservoir

Porosity of low-permeability reservoir

Permeability of low-permeability reservoir

Facies of low-permeability reservoir

Thermal maturity

Well data on production and shows

Pressure data

Estimated ultimate recoveries (EURs)

Maps and Data Sets Describing Continuous Accumulations in Coal Reservoirs

Extent of coal

Thickness of coal

Rank of coal

Depth of coal

Well data on production and shows

Pressure data

Estimated ultimate recoveries (EURs)

\section{Estimated Ultimate Recovery per Well}

Distributions estimating the productivities of wells in the untested area are entered in lines $5 \mathrm{a}$ through $6 \mathrm{~b}$. They are in two sets. Lines $5 \mathrm{a}$ and $5 \mathrm{~b}$ are for the sweet spots and lines $6 \mathrm{a}$ and $6 \mathrm{~b}$ are for the non-sweet spots.

The future success ratio within the sweet spots is estimated by the distribution in line $5 \mathrm{a}$. This success ratio is the percent of wells that will produce at least the minimum EUR given in the "Characteristics of Assessment Unit" section of the input form. It may be similar to the historic success ratio given in that section or could vary because of geologic differences in the undrilled area.

The average EUR in the untested sweet spots is estimated by the distribution in line $5 \mathrm{~b}$. Because thousands to hundreds of thousands of wells are involved in this calculation, only the average EUR and its uncertainty are relevant.

The future success ratio and average EUR for non-sweet spots are estimated by the distributions in lines $6 \mathrm{a}$ and $6 \mathrm{~b}$. In some AUs, sufficient production history has delineated sweet spots and non-sweet spots and estimates of future success ratios and average EURs can be supported by drilling and production data from each area. In other AUs, most of the drilling and production has taken place in known sweet spots. In those cases, the distributions in lines $6 \mathrm{a}$ and $6 \mathrm{~b}$ might be based on those wells that were more exploratory (those drilled relatively distant from previously drilled wells).

Triangular distributions are used for lines $5 \mathrm{a}$ and $6 \mathrm{a}$ because they represent the uncertainty about a single value that exists in nature but is unknown. Triangular distributions allow the distributions to be skewed in either direction. The distributions for lines $5 \mathrm{~b}$ and $6 \mathrm{~b}$ are generally expected to be heavily right skewed, so shifted truncated lognormal distributions are used.

For partially developed AUs, the main information source is analysis of production data from wells in that AU. The historical success ratios and EUR distributions may not exactly reflect what is expected for the untested part of the AU, as geological differences may exist between the tested and untested areas. The historical drilling record may also reflect changes in engineering practice with time. To give insight into these factors, a set of standardized plots are developed from the historical data. These plots highlight trends in the production information both temporally and spatially.

Many geologic factors affect the success ratios and EURs. The effects of geology are only partially understood. Nevertheless, geological information can be useful in estimating the changes in success ratios and EURs into the future, as well as estimating what analogs may best be used for hypothetical or poorly explored AUs. The geologic factors that should be considered in the estimation of distributions in lines 5 and 6 are listed below.

Geologic Factors to Consider for Continuous Accumulations in Shale Reservoirs

Thickness

TOC

Pressures

Mineralogy

Mechanical stratigraphy (such as existence of frac barriers)

Organic geochemistry

Natural fractures

Geologic Factors to Consider for Continuous Accumulations in Low-Permeability Clastic or Carbonate Reservoirs

Thickness

Pressures

Mineralogy

Organic geochemistry

Geologic Factors to Consider for Continuous Accumulations in Coal Reservoirs
Thickness
Rank
Pressures
Mineralogy
Mechanical stratigraphy
Organic geochemistry
Gas geochemistry
Cleating
Ash content 


\section{Uncertainty about Average Coproduct Ratios for Untested Wells}

Each AU is classified as having a primary petroleum product, either oil or gas. If the overall gas to oil ratio is 20,000 cubic feet per barrel or more, the primary product is gas; otherwise the primary product is oil. In either case, other products exist in the accumulation. Oil accumulations are considered to have some volume of associated/dissolved gas. Also, some natural gas liquids (NGLs) are considered to be dissolved in the associated/dissolved gas. Some gas accumulations produce volumes of liquids that were dissolved in the gas at reservoir conditions.

In order to estimate the volumes of these other products, coproduct ratios are applied to the estimated volumes of the primary product (Appendix 1, page 2). The distributions represent the uncertainty about the average ratios for the entire AU. Generally, the coproduct ratios based on historic production data are good initial estimates of the coproduct ratios in the remaining untested area of the AU.

\section{Selected Ancillary Data for Untested Wells}

Although not used in calculating volumes of resource, ancillary data are provided for the characteristics of the petroleum fluids and reservoirs (Appendix 1, page 2). These data may be useful in any additional analyses, such as economic analyses. Just as in the case of coproduct ratios, historical data generally provide good initial estimates of what the characteristics could be for the untested area of the AU.

\section{Allocations}

There are commonly some practical needs to present estimated volumes of resource allocated to particular geographic entities - states, onshore-offshore, by land ownership, and so on. The rough allocations are done with point estimates (of the mean). Distributions of the allocation percents are not given because of the large statistical problems associated with a set of allocations constrained to total 100 percent. Area percents of that geographic entity within the AU are calculated using a GIS (geographic information system). In the absence of any information suggesting that part of the AU has more resource per unit area, the area percent can be used as a default estimated volume percent allocation.

\section{Use of Analogs}

The methodology described in this report can be used for maturely developed AUs. In these cases, the data can be used to estimate the input distributions in a relatively direct manner. Some AUs, however, are immaturely developed or even hypothetical. In these cases, the input distributions must be derived by comparison with the geologic and production data in analog areas. Construction of analog databases makes this easier.

\section{Summary}

The new USGS methodology for assessing continuous (unconventional) oil and gas resources offers significant improvements over the previous version. Most importantly, uncertainty about the average EUR is directly assessed and incorporated into the calculations. An option is added to treat the success ratio and EUR distribution as either representing one population or a mixture of two populations. Also, the theoretical concept of cells has been eliminated, and well results are used more directly. These changes are especially important for improving assessments of continuous resources in frontier or near-frontier deposits.

\section{References Cited}

Crovelli, R.A., 2000, Analytic resource assessment method for continuous (unconventional) oil and gas accumulationsthe "ACCESS" method: U.S. Geological Survey Open-File Report 00-044, 34 p.

Crovelli, R.A., 2003, Analytic resource assessment method for continuous petroleum accumulations - the ACCESS assessment method, chap. 22, in U.S. Geological Survey Uinta-Piceance Assessment Team, Petroleum Systems and Geologic Assessment of Oil and Gas in the UintaPiceance Province, Utah and Colorado: U.S. Geological Survey Digital Data Series DDS-69-B, 10 p. (Also available at http://pubs.usgs.gov/dds/dds-069/dds-069-b/.)

Klett, T.R., and Charpentier, R.R., 2003, FORSPAN model users guide: U.S. Geological Survey Open-File Report 03-354, $37 \mathrm{p}$.

Klett, T.R., Charpentier, R.R., and Le, P.A., 2003, Tabular data and graphical images in support of the U.S. Geological Survey National Oil and Gas Assessment-the UintaPiceance province (5020), chap. 28, in U.S. Geological Survey Uinta-Piceance Assessment Team, Petroleum Systems and Geologic Assessment of Oil and Gas in the Uinta-Piceance Province, Utah and Colorado: U.S. Geological Survey Digital Data Series DDS-69-B, 16 p. (Also available at http://pubs.usgs.gov/dds/dds-069/ $d d s-069-b /$.

Klett, T.R., and Schmoker, J.W., 2003, U.S. Geological Survey input-data form and operational procedure for the assessment of continuous petroleum accumulations, chap. 18, in U.S. Geological Survey Uinta-Piceance Assessment Team, Petroleum Systems and Geologic Assessment of Oil and Gas in the Uinta-Piceance Province, Utah and Colorado: U.S. Geological Survey Digital Data Series DDS-69-B, 8 p. (Also available at http://pubs.usgs.gov/ $d d s / d d s-069 / d d s-069-b /$. 
Klett, T.R., Schmoker, J.W., Charpentier, R.R., Ahlbrandt, T.S., and Ulmishek, G.F., 2003, Glossary, chap. 25, in U.S. Geological Survey Uinta-Piceance Assessment Team, Petroleum Systems and Geologic Assessment of Oil and Gas in the Uinta-Piceance Province, Utah and Colorado: U.S. Geological Survey Digital Data Series DDS-69-B, 3 p. (Also available at $h t t p: / / p u b s . u s g s . g o v / d d s / d d s-069 / d d s-069-b /$.

Microsoft, 2007, Microsoft Office Excel 2007 software: Microsoft Corporation, Redmond, Washington, available at http://www.microsoft.com.

Palisade, 2010,@Risk software, version 5.5: Palisade Corporation, Ithaca, New York, available at $h t t p: / / w w w$. palisade.com.

Schmoker, J.W., 1995, Methodology for assessing continuoustype (unconventional) hydrocarbon accumulations, in Gautier, D.L., Dolton, G.L., Takahashi, K.I., and Varnes, K.L., eds., 1995 National Assessment of United States Oil and Gas Resources-Results, methodology, and supporting data: U.S. Geological Survey Digital Data Series DDS-30, 27 p. (Also available at $h t t p: / / p u b s . u s g s . g o v / d d s / d d s-030 /$.)

Schmoker, J.W., 2003, U.S. Geological Survey assessment concepts for continuous petroleum accumulations, chap. 17, in U.S. Geological Survey Uinta-Piceance Assessment Team, Petroleum Systems and Geologic Assessment of Oil and Gas in the Uinta-Piceance Province, Utah and Colorado: U.S. Geological Survey Digital Data Series DDS69-B, 7 p. (Also available at http://pubs.usgs.gov/dds/ $d d s-069 / d d s-069-b /$.

Schmoker, J.W., Fouch, T.D., and Charpentier, R.R., 1996, Gas in the Uinta basin, Utah-Resources in continuous accumulations: The Mountain Geologist, v. 33, no. 4, p. $95-104$. 
Appendix 1. Input data form for continuous accumulations 


\section{INPUT DATA FORM FOR CONTINUOUS ACCUMULATIONS}

(version 1.0, November 5, 2010)

IDENTIFICATION INFORMATION

Assessment Geologist:

Region:

Province:

Total Petroleum System:

Assessment Unit:

Date:

Number:

Number:

Number:

Based on Data as of:

Number:

Notes from Assessor:

\section{CHARACTERISTICS OF ASSESSMENT UNIT}

$\begin{aligned} \text { Assessment-unit type: } \quad \text { oil }(<20,000 \mathrm{cfg} / \mathrm{bo}) & \text { heavy oil }(<10 \mathrm{API})\end{aligned}$

Well type:

Major reservoir type (Choose one.):

vertical horizontal

shale

coal low-permeability clastics low-permeability carbonates diatomite

Minimum EUR per well (mmbo for oil AU; bcfg for gas AU)

Number of tested wells:

Number of tested wells with EUR > minimum:

Historic success ratio, tested wells (\%)

Assessment-Unit Probability:

What is the probability that an accumulation with producible resources exists?

\section{NUMBER OF UNDRILLED WELLS WITH POTENTIAL FOR ADDITIONS TO RESERVES}

1. Productive area of accumulation (acres): (triangular)

calculated mean minimum mode maximum

2. Uncertainty about average drainage area of wells (acres): (triangular) calculated mean minimum mode maximum

2a. Distribution of drainage areas of individual wells (acres): (shifted truncated lognormal) calculated mean minimum median maximum

3. Percentage of total assessment-unit area that is untested (\%): (triangular) calculated mean minimum mode maximum 


\section{NUMBER OF UNDRILLED WELLS WITH POTENTIAL FOR ADDITIONS TO RESERVES}

(Continued)

4. Percentage of untested assessment-unit area in sweet spots (\%): (triangular)

calculated mean

minimum

mode

maximum

\section{ESTIMATED ULTIMATE RECOVERY (EUR) PER WELL \\ SWEET SPOTS}

5a. Future success ratio (\%): (triangular)

calculated mean

minimum

mode

maximum

5b. Uncertainty about average EUR (mmbo for oil; bcfg for gas): (shifted truncated lognormal)

calculated mean

minimum

median

maximum

\section{NON-SWEET SPOTS}

6a. Future success ratio (\%): (triangular)

calculated mean

minimum

mode

maximum

6b. Uncertainty about average EUR (mmbo for oil; bcfg for gas): (shifted truncated lognormal) calculated mean

minimum

median

maximum

\section{UNCERTAINTY ABOUT AVERAGE COPRODUCT RATIOS FOR UNTESTED WELLS}

(triangular)

Oil assessment unit:

Gas/oil ratio (cfg/bo)

minimum

mode

maximum

NGL/gas ratio (bngl/mmcfg)

Gas assessment unit:

Liquids/gas ratio (bliq/mmcfg) 
Assessment Unit (name, no.)

\section{SELECTED ANCILLARY DATA FOR UNTESTED WELLS}

(no specified distribution type)

\begin{tabular}{|c|c|c|c|c|c|}
\hline Oil assessment unit: & minimum & & median & & maximum \\
\hline $\begin{array}{l}\text { API gravity of oil (degrees) } \\
\text { Sulfur content of oil (\%) }\end{array}$ & & & & & \\
\hline Depth (m) of water (if applicable) & & & & & \\
\hline Drilling depth $(\mathrm{m})$ & minimum & $\mathrm{F} 75$ & median & $\mathrm{F} 25$ & maximum \\
\hline Gas assessment unit: & minimum & & median & & maximum \\
\hline Inert-gas content (\%) & & & & & \\
\hline $\mathrm{CO}_{2}$ content $(\%)$ & & & & & \\
\hline Hydrogen sulfide content (\%) & & & & & \\
\hline Heating value (BTU) & & & & & \\
\hline Depth (m) of water (if applicable) & & & & & \\
\hline Drilling depth (m) & minimum & F75 & median & $\mathrm{F} 25$ & maximum \\
\hline
\end{tabular}

Completion practices:

1. Typical well-completion practices (conventional, open hole, open cavity, other)

2. Fraction of wells drilled that are typically stimulated

3. Predominant type of stimulation (none, frac, acid, other)

4. Historic fraction of wells drilled that are horizontal 
Assessment Unit (name, no.)

\section{ALLOCATIONS OF POTENTIAL ADDITIONS TO RESERVES TO STATES \\ Surface Allocations (uncertainty of a fixed value)}

1.

mean VOLUME \% in entity

2. mean VOLUME \% in entity

3. mean VOLUME \% in entity

4. mean VOLUME \% in entity

5. mean VOLUME \% in entity

6. mean VOLUME \% in entity

7. mean VOLUME \% in entity

8. mean VOLUME \% in entity

9.

mean VOLUME \% in entity 10. mean VOLUME \% in entity is $\%$ of the AREA of the AU

is $\%$ of the AREA of the AU

is $\%$ of the AREA of the AU

is $\%$ of the AREA of the AU

is $\%$ of the AREA of the AU

is $\%$ of the AREA of the AU

is $\%$ of the AREA of the AU

is $\%$ of the AREA of the AU

is $\%$ of the AREA of the AU

is $\%$ of the AREA of the AU 


\section{ALLOCATIONS OF POTENTIAL ADDITIONS TO RESERVES TO GENERAL LAND OWNERSHIPS Surface Allocations (uncertainty of a fixed value)}

1. Federal Lands

mean VOLUME \% in entity

2. Private Lands

mean VOLUME \% in entity

3. Tribal Lands

mean VOLUME \% in entity

4. Other Lands

mean VOLUME \% in entity

5. State 1 Lands

mean VOLUME \% in entity

6.

mean VOLUME \% in entity

7.

mean VOLUME \% in entity

8.

mean VOLUME \% in entity

9.

mean VOLUME \% in entity

10.

mean VOLUME \% in entity is $\%$ of the AREA of the AU

is $\%$ of the AREA of the AU

is $\%$ of the AREA of the AU

is $\%$ of the AREA of the AU

is $\%$ of the AREA of the AU

is $\%$ of the AREA of the AU

is $\%$ of the AREA of the AU

is $\%$ of the AREA of the AU

is $\%$ of the AREA of the AU

is $\%$ of the AREA of the AU 


\section{ALLOCATIONS OF POTENTIAL ADDITIONS TO RESERVES TO FEDERAL LAND SUBDIVISIONS Surface Allocations (uncertainty of a fixed value)}

1. Bureau of Land Management (BLM) mean VOLUME \% in entity

2. BLM Wilderness Areas (BLMW) mean VOLUME \% in entity

3. BLM Roadless Areas (BLMR) mean VOLUME \% in entity

4. National Park Service (NPS) mean VOLUME \% in entity

5. NPS Wilderness Areas (NPSW) mean VOLUME \% in entity

6. NPS Protected Withdrawals (NPSP) mean VOLUME \% in entity

7. US Forest Service (FS) mean VOLUME \% in entity

8. USFS Wilderness Areas (FSW) mean VOLUME \% in entity

9. USFS Roadless Areas (FSR) mean VOLUME \% in entity

10. USFS Protected Withdrawals (FSP) mean VOLUME \% in entity is $\%$ of the AREA of the AU

is $\%$ of the AREA of the AU

is $\%$ of the AREA of the AU

is $\%$ of the AREA of the AU

is $\%$ of the AREA of the AU

is $\%$ of the AREA of the AU

is $\%$ of the AREA of the AU

is $\%$ of the AREA of the AU

is $\%$ of the AREA of the AU

is $\%$ of the AREA of the AU 
11. US Fish and Wildlife Service (FWS) mean VOLUME \% in entity

12. USFWS Wilderness Areas (FWSW) mean VOLUME \% in entity

13. USFWS Protected Withdrawals (FWSP) mean VOLUME \% in entity

14. Wilderness Study Areas (WS) mean VOLUME \% in entity

15. Department of Energy (DOE) mean VOLUME \% in entity

16. Department of Defense (DOD) mean VOLUME \% in entity

17. Bureau of Reclamation (BOR) mean VOLUME \% in entity

18. Tennessee Valley Authority (TVA) mean VOLUME \% in entity

19. Other Federal mean VOLUME \% in entity

20.

mean VOLUME \% in entity $\%$ of the AREA of the AU

is $\%$ of the AREA of the AU

is $\%$ of the AREA of the AU

is $\%$ of the AREA of the AU

is $\%$ of the AREA of the AU

is $\%$ of the AREA of the AU

is $\%$ of the AREA of the AU

is $\%$ of the AREA of the AU

is $\%$ of the AREA of the AU

is $\%$ of the AREA of the AU 
Assessment Unit (name, no.)

\section{ALLOCATIONS OF POTENTIAL ADDITIONS TO RESERVES TO ECOSYSTEMS \\ Surface Allocations (uncertainty of a fixed value)}

1.

mean VOLUME \% in entity

2. mean VOLUME \% in entity

3. mean VOLUME \% in entity

4. mean VOLUME \% in entity

5. mean VOLUME \% in entity

6. mean VOLUME \% in entity

7. mean VOLUME \% in entity

8. mean VOLUME \% in entity

9. mean VOLUME \% in entity 10. mean VOLUME \% in entity is $\%$ of the AREA of the AU

is $\%$ of the AREA of the AU

is $\%$ of the AREA of the AU

is $\%$ of the AREA of the AU

is $\%$ of the AREA of the AU

is $\%$ of the AREA of the AU

is $\%$ of the AREA of the AU

is $\%$ of the AREA of the AU

is $\%$ of the AREA of the AU

is $\%$ of the AREA of the AU 



\section{Appendix 2. Monte Carlo program for assessment of continuous accumulations}

The attached program, Continuous2010v2, is a Monte Carlo program that uses @Risk software (Palisade, 2010) to run within Microsoft Excel (Microsoft, 2007). Before using the program, the user must purchase and install both of these commercially available software packages. Once installed, the Continuous2010v2 program runs normally like any other @ Risk program. The user is referred to the documentation for those software programs for general instructions on running the program.

Continuous2010v2 includes several spreadsheets. All the input is to be entered on the "Input" spreadsheet in the yellow boxes. The spreadsheet "RiskTemplate_Input" is provided to the user who wishes to add a record of the input data to reports generated by@Risk.

"Although this program has been used by the USGS, no warranty, expressed or implied, is made by the USGS or the United States Government as to the accuracy and functioning of the program and related program material nor shall the fact of distribution constitute any such warranty, and no responsibility is assumed by the USGS in connection therewith." 
USGS 2010 Continuous Methodology

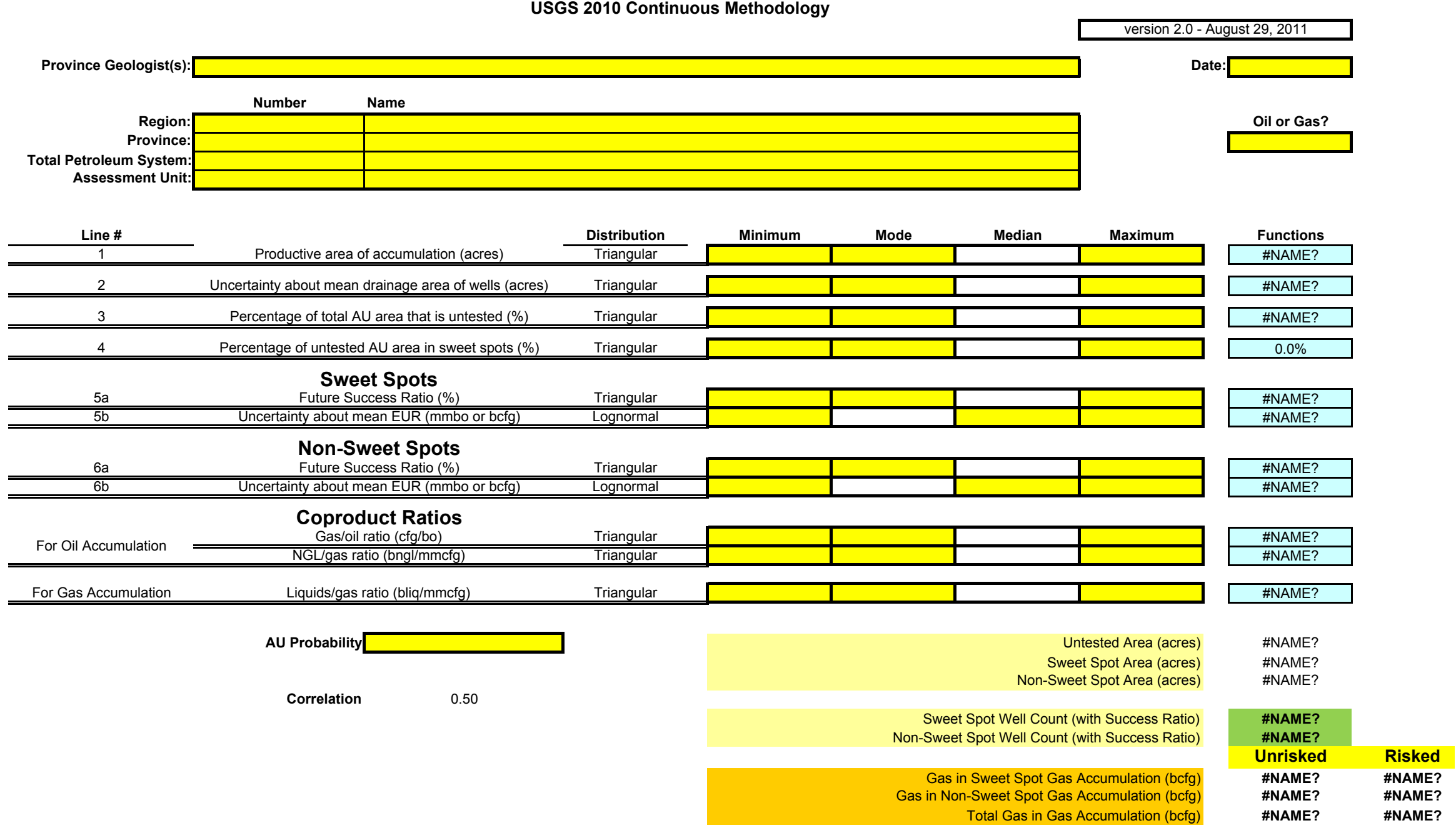




\begin{tabular}{|l|c|c|c|}
\hline @RISK Correlations & & & 0.5 \\
\hline & 1 & 0.5 & 0.5 \\
\hline & 0.5 & 0 & 0 \\
\hline
\end{tabular}

Uniform Probability \#NAME?

mean \#NUM! s.d. \#NUM!

s.d. \#NUM
Parameters of associated normal \#NUM! sigma \#NUM!

\#NUM!

sigma

\begin{tabular}{|c|c|c|c|}
\hline $\begin{array}{l}\text { Gas in Sweet Spot Gas Accumulation (bcfg) } \\
\text { Gas in Non-Sweet Spot Gas Accumulation (bcfg) } \\
\text { Total Gas in Gas Accumulation (bcfg) }\end{array}$ & $\begin{array}{l}\text { \#NAME? } \\
\text { \#NAME? } \\
\text { \#NAME? }\end{array}$ & $\begin{array}{l}\text { Risked Gas in Sweet Spot Gas Accumulation (bcfg) } \\
\text { Risked Gas in Non-Sweet Spot Gas Accumulation (bcfg) } \\
\text { Risked Total Gas in Gas Accumulation (bcfg) }\end{array}$ & $\begin{array}{l}\text { \#NAME? } \\
\text { \#NAME? } \\
\text { \#NAME? }\end{array}$ \\
\hline $\begin{array}{l}\text { Oil in Sweet Spot Oil Accumulation (mmbo) } \\
\text { Oiil in Non-Sweet Spot Oil Accumulation (mmbo) } \\
\text { Total Oil in Oil Accumulation (mmbo) }\end{array}$ & $\begin{array}{l}\text { \#NAME? } \\
\text { \#NAME? } \\
\text { \#NAME? }\end{array}$ & $\begin{array}{l}\text { Risked Oil in Sweet Spot Oil Accumulation (mmbo) } \\
\text { Risked Oil in Non-Sweet Spot Oil Accumulation (mmbo) } \\
\text { Risked Total Oil in Oil Accumulation (mmbo) }\end{array}$ & $\begin{array}{l}\text { \#NAME? } \\
\text { \#NAME? } \\
\text { \#NAME? }\end{array}$ \\
\hline $\begin{array}{l}\text { Gas in Sweet Spot Oil Accumulation (bcfg) } \\
\text { Gas in Non-Sweet Spot Oil Accumulation (bcfg) } \\
\text { Total Gas in Oil Accumulation (bcfg) } \\
\text { NGL in Sweet Spot Oil Accumulation (mmbo) } \\
\text { NGL in Non-Sweet Spot Oil Accumulation (bcfg) } \\
\text { Total NGL in Oil Accumulation (mmbo) } \\
\text { Liquids in Sweet Spot Gas Accumulation (mmbo) } \\
\text { Liquids in Non-Sweet Spot Gas Accumulation (mmbo) } \\
\text { Total Liquids in Gas Accumulation (mmbo) }\end{array}$ & $\begin{array}{l}\text { \#NAME? } \\
\text { \#NAME? } \\
\text { \#NAME? } \\
\text { \#NAME? } \\
\text { \#NAME? } \\
\text { \#NAME? } \\
\text { \#NAME? } \\
\text { \#NAME? } \\
\text { \#NAME? }\end{array}$ & $\begin{array}{l}\text { Risked Gas in Sweet Spot Oil Accumulation (bcfg) } \\
\text { Risked Gas in Non-Sweet Spot Oil Accumulation (bcfg) } \\
\text { Risked Total Gas in Oil Accumulation (bcfg) } \\
\text { Risked NGL in Sweet Spot Oil Accumulation (mmbo) } \\
\text { Risked NGL in Non-Sweet Spot Oil Accumulation (mmbo) } \\
\text { Risked Total NGL in Oil Accumulation (mmbo) } \\
\text { Risked Liquids in Sweet Spot Gas Accumulation (mmbo) } \\
\text { Risked Liquids in Non-Sweet Spot Gas Accumulation (mmbo) } \\
\text { Risked Total Liquids in Gas Accumulation (mmbo) }\end{array}$ & $\begin{array}{l}\text { \#NAME? } \\
\text { \#NAME? } \\
\text { \#NAME? } \\
\text { \#NAME? } \\
\text { \#NAME? } \\
\text { \#NAME? } \\
\text { \#NAME? } \\
\text { \#NAME? } \\
\text { \#NAME? }\end{array}$ \\
\hline $\begin{array}{l}\text { EUR Distribution Sweet Spot } \\
\text { EUR Distribution Non-Sweet Spot }\end{array}$ & $\begin{array}{l}\text { \#NAME? } \\
\text { \#NAME? }\end{array}$ & & \\
\hline
\end{tabular}




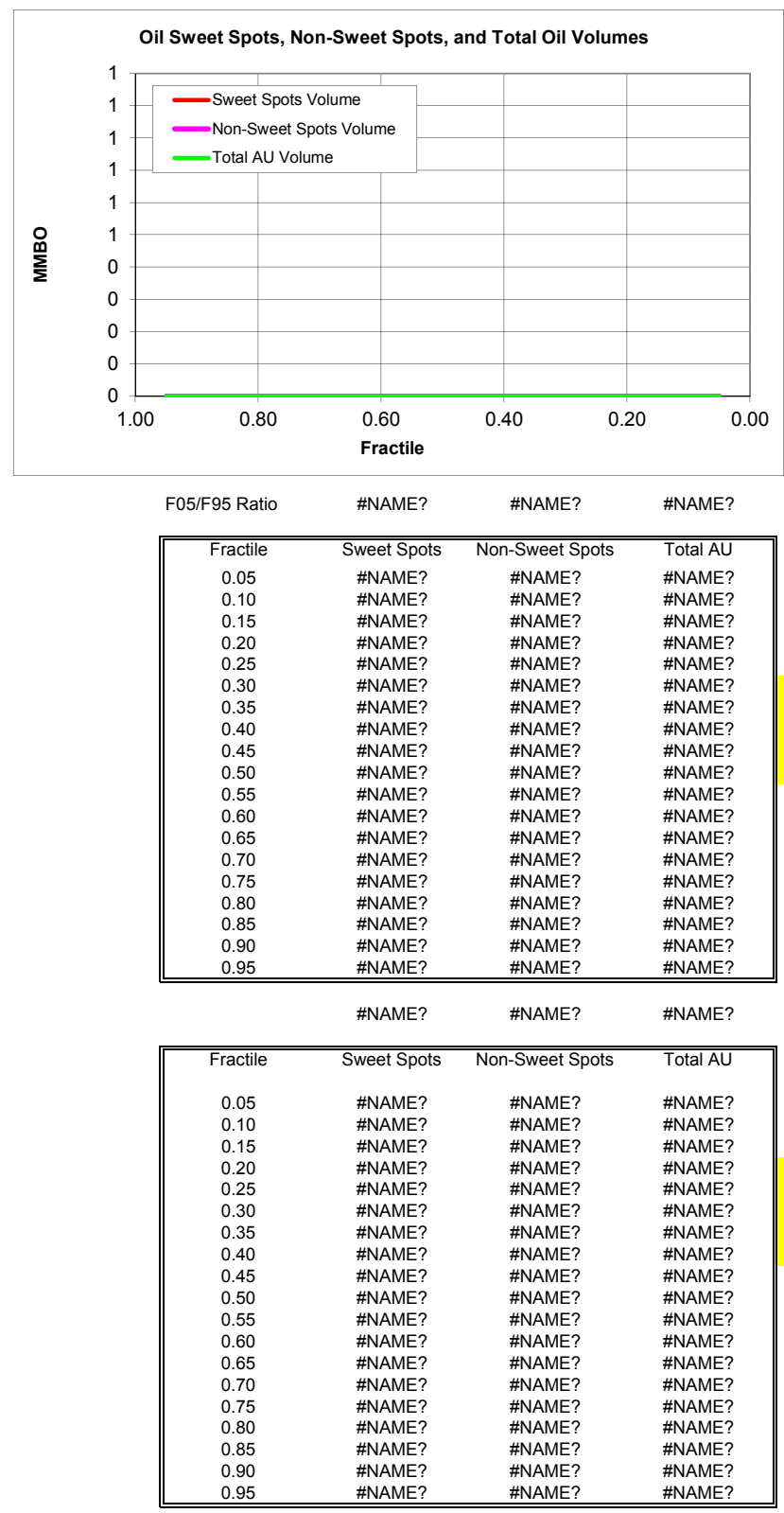

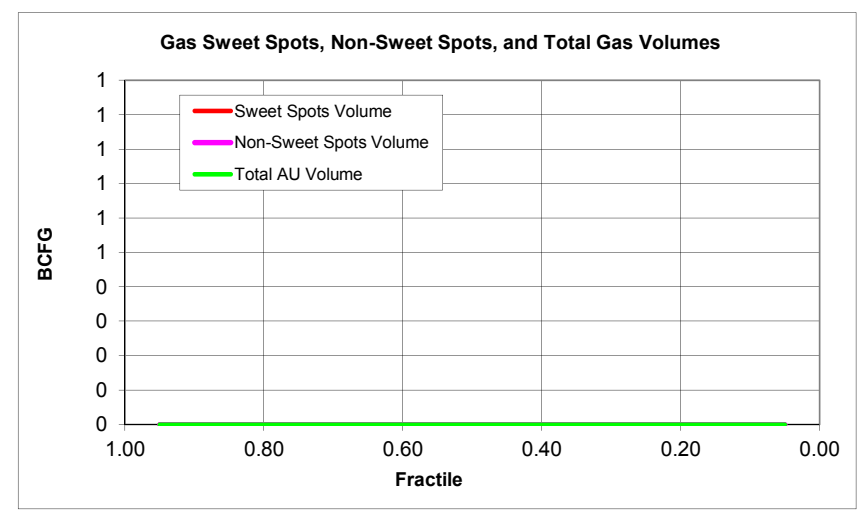

Risked Volumes

\begin{tabular}{|c|c|c|c|}
\hline Fractile & Sweet Spots & Non-Sweet Spots & Total AU \\
\hline 0.05 & \#NAME? & \#NAME? & \#NAME? \\
\hline 0.10 & \#NAME? & \#NAME? & \#NAME? \\
\hline 0.15 & \#NAME? & \#NAME? & \#NAME? \\
\hline 0.20 & \#NAME? & \#NAME? & \#NAME? \\
\hline 0.25 & \#NAME? & \#NAME? & \#NAME? \\
\hline 0.30 & \#NAME? & \#NAME? & \#NAME? \\
\hline 0.35 & \#NAME? & \#NAME? & \#NAME? \\
\hline 0.40 & \#NAME? & \#NAME? & \#NAME? \\
\hline 0.45 & \#NAME? & \#NAME? & \#NAME? \\
\hline 0.50 & \#NAME? & \#NAME? & \#NAME? \\
\hline 0.55 & \#NAME? & \#NAME? & \#NAME? \\
\hline 0.60 & \#NAME? & \#NAME? & \#NAME? \\
\hline 0.65 & \#NAME? & \#NAME? & \#NAME? \\
\hline 0.70 & \#NAME? & \#NAME? & \#NAME? \\
\hline 0.75 & \#NAME? & \#NAME? & \#NAME? \\
\hline 0.80 & \#NAME? & \#NAME? & \#NAME? \\
\hline 0.85 & \#NAME? & \#NAME? & \#NAME? \\
\hline 0.90 & \#NAME? & \#NAME? & \#NAME? \\
\hline 0.95 & \#NAME? & \#NAME? & \#NAME? \\
\hline
\end{tabular}

GAS

\begin{tabular}{|c|c|c|c|}
\hline $\begin{array}{l}\text { Fractile } \\
\end{array}$ & Sweet Spots & "Non-Sweet Spots & "Total AU \\
\hline 0.05 & \#NAME? & \#NAME? & \#NAME? \\
\hline 0.10 & \#NAME? & \#NAME? & \#NAME? \\
\hline 0.15 & \#NAME? & \#NAME? & \#NAME? \\
\hline 0.20 & \#NAME? & \#NAME? & \#NAME? \\
\hline 0.25 & \#NAME? & \#NAME? & \#NAME? \\
\hline 0.30 & \#NAME? & \#NAME? & \#NAME? \\
\hline 0.35 & \#NAME? & \#NAME? & \#NAME? \\
\hline 0.40 & \#NAME? & \#NAME? & \#NAME? \\
\hline 0.45 & \#NAME? & \#NAME? & \#NAME? \\
\hline 0.50 & \#NAME? & \#NAME? & \#NAME? \\
\hline 0.55 & \#NAME? & \#NAME? & \#NAME? \\
\hline 0.60 & \#NAME? & \#NAME? & \#NAME? \\
\hline 0.65 & \#NAME? & \#NAME? & \#NAME? \\
\hline 0.70 & \#NAME? & \#NAME? & \#NAME? \\
\hline 0.75 & \#NAME? & \#NAME? & \#NAME? \\
\hline 0.80 & \#NAME? & \#NAME? & \#NAME? \\
\hline 0.85 & \#NAME? & \#NAME? & \#NAME? \\
\hline 0.90 & \#NAME? & \#NAME? & \#NAME? \\
\hline 0.95 & \#NAME? & \#NAME? & \#NAME? \\
\hline
\end{tabular}


Gas in Oil Accumulation (bcfg)

\#NAME?

\begin{tabular}{|c|c|c|c|}
\hline F05/F95 Ratio & \#NAME? & \#NAME? & \#NAME? \\
\hline Fractile & Sweet Spots & "Non-Sweet Spots & "Total AU \\
\hline 0.05 & \#NAME? & \#NAME? & \#NAME? \\
\hline 0.10 & \#NAME? & \#NAME? & \#NAME? \\
\hline 0.15 & \#NAME? & \#NAME? & \#NAME? \\
\hline 0.20 & \#NAME? & \#NAME? & \#NAME? \\
\hline 0.25 & \#NAME? & \#NAME? & \#NAME? \\
\hline 0.30 & \#NAME? & \#NAME? & \#NAME? \\
\hline 0.35 & \#NAME? & \#NAME? & \#NAME? \\
\hline 0.40 & \#NAME? & \#NAME? & \#NAME? \\
\hline 0.45 & \#NAME? & \#NAME? & \#NAME? \\
\hline 0.50 & \#NAME? & \#NAME? & \#NAME? \\
\hline 0.55 & \#NAME? & \#NAME? & \#NAME? \\
\hline 0.60 & \#NAME? & \#NAME? & \#NAME? \\
\hline 0.65 & \#NAME? & \#NAME? & \#NAME? \\
\hline 0.70 & \#NAME? & \#NAME? & \#NAME? \\
\hline 0.75 & \#NAME? & \#NAME? & \#NAME? \\
\hline 0.80 & \#NAME? & \#NAME? & \#NAME? \\
\hline 0.85 & \#NAME? & \#NAME? & \#NAME? \\
\hline 0.90 & \#NAME? & \#NAME? & \#NAME? \\
\hline 0.95 & \#NAME? & \#NAME? & \#NAME? \\
\hline
\end{tabular}

NGL in Oil Accumulation (mmbNGL)

\#NAME?

\begin{tabular}{|c|c|c|c|}
\hline F05/F95 Ratio & \#NAME? & \#NAME? & \#NAME? \\
\hline$\overline{\text { Fractile }}$ & Sweet Spots & "Non-Sweet Spots & Total AU \\
\hline 0.05 & \#NAME? & \#NAME? & \#NAME? \\
\hline 0.10 & \#NAME? & \#NAME? & \#NAME? \\
\hline 0.15 & \#NAME? & \#NAME? & \#NAME? \\
\hline 0.20 & \#NAME? & \#NAME? & \#NAME? \\
\hline 0.25 & \#NAME? & \#NAME? & \#NAME? \\
\hline 0.30 & \#NAME? & \#NAME? & \#NAME? \\
\hline 0.35 & \#NAME? & \#NAME? & \#NAME? \\
\hline 0.40 & \#NAME? & \#NAME? & \#NAME? \\
\hline 0.45 & \#NAME? & \#NAME? & \#NAME? \\
\hline 0.50 & \#NAME? & \#NAME? & \#NAME? \\
\hline 0.55 & \#NAME? & \#NAME? & \#NAME? \\
\hline 0.60 & \#NAME? & \#NAME? & \#NAME? \\
\hline 0.65 & \#NAME? & \#NAME? & \#NAME? \\
\hline 0.70 & \#NAME? & \#NAME? & \#NAME? \\
\hline 0.75 & \#NAME? & \#NAME? & \#NAME? \\
\hline 0.80 & \#NAME? & \#NAME? & \#NAME? \\
\hline 0.85 & \#NAME? & \#NAME? & \#NAME? \\
\hline 0.90 & \#NAME? & \#NAME? & \#NAME? \\
\hline 0.95 & \#NAME? & \#NAME? & \#NAME? \\
\hline
\end{tabular}

Liquids in Gas Accumulation

\#NAME?

F05/F95 Ratio \#NAME? \#NAME? \#NAME?

\begin{tabular}{|c|c|c|c|}
\hline Fractile & S Sweet Spots & "Non-Sweet Spots & Total AU \\
\hline 0.05 & \#NAME? & \#NAME? & \#NAME? \\
\hline 0.10 & \#NAME? & \#NAME? & \#NAME? \\
\hline 0.15 & \#NAME? & \#NAME? & \#NAME? \\
\hline 0.20 & \#NAME? & \#NAME? & \#NAME? \\
\hline 0.25 & \#NAME? & \#NAME? & \#NAME? \\
\hline 0.30 & \#NAME? & \#NAME? & \#NAME? \\
\hline 0.35 & \#NAME? & \#NAME? & \#NAME? \\
\hline 0.40 & \#NAME? & \#NAME? & \#NAME? \\
\hline 0.45 & \#NAME? & \#NAME? & \#NAME? \\
\hline 0.50 & \#NAME? & \#NAME? & \#NAME? \\
\hline 0.55 & \#NAME? & \#NAME? & \#NAME? \\
\hline 0.60 & \#NAME? & \#NAME? & \#NAME? \\
\hline 0.65 & \#NAME? & \#NAME? & \#NAME? \\
\hline 0.70 & \#NAME? & \#NAME? & \#NAME? \\
\hline 0.75 & \#NAME? & \#NAME? & \#NAME? \\
\hline 0.80 & \#NAME? & \#NAME? & \#NAME? \\
\hline 0.85 & \#NAME? & \#NAME? & \#NAME? \\
\hline 0.90 & \#NAME? & \#NAME? & \#NAME? \\
\hline 0.95 & \#NAME? & \#NAME? & \#NAME? \\
\hline
\end{tabular}

Risked Gas in Oil Accumulation (bcfg)

\#NAME?

\begin{tabular}{|c|c|c|c|}
\hline Fractile & Sweet Spots & Non-Sweet Spots & Total AU \\
\hline 0.05 & \#NAME? & \#NAME? & \#NAME? \\
\hline 0.10 & \#NAME? & \#NAME? & \#NAME? \\
\hline 0.15 & \#NAME? & \#NAME? & \#NAME? \\
\hline 0.20 & \#NAME? & \#NAME? & \#NAME? \\
\hline 0.25 & \#NAME? & \#NAME? & \#NAME? \\
\hline 0.30 & \#NAME? & \#NAME? & \#NAME? \\
\hline 0.35 & \#NAME? & \#NAME? & \#NAME? \\
\hline 0.40 & \#NAME? & \#NAME? & \#NAME? \\
\hline 0.45 & \#NAME? & \#NAME? & \#NAME? \\
\hline 0.50 & \#NAME? & \#NAME? & \#NAME? \\
\hline 0.55 & \#NAME? & \#NAME? & \#NAME? \\
\hline 0.60 & \#NAME? & \#NAME? & \#NAME? \\
\hline 0.65 & \#NAME? & \#NAME? & \#NAME? \\
\hline 0.70 & \#NAME? & \#NAME? & \#NAME? \\
\hline 0.75 & \#NAME? & \#NAME? & \#NAME? \\
\hline 0.80 & \#NAME? & \#NAME? & \#NAME? \\
\hline 0.85 & \#NAME? & \#NAME? & \#NAME? \\
\hline 0.90 & \#NAME? & \#NAME? & \#NAME? \\
\hline 0.95 & \#NAME? & \#NAME? & \#NAME? \\
\hline
\end{tabular}

Risked NGL in Oil Accumulation (mmbNGL)

\#NAME?

\begin{tabular}{|c|c|c|c|}
\hline Fractile & Sweet Spots & Non-Sweet Spots & Total AU \\
\hline 0.05 & \#NAME? & \#NAME? & \#NAME? \\
\hline 0.10 & \#NAME? & \#NAME? & \#NAME? \\
\hline 0.15 & \#NAME? & \#NAME? & \#NAME? \\
\hline 0.20 & \#NAME? & \#NAME? & \#NAME? \\
\hline 0.25 & \#NAME? & \#NAME? & \#NAME? \\
\hline 0.30 & \#NAME? & \#NAME? & \#NAME? \\
\hline 0.35 & \#NAME? & \#NAME? & \#NAME? \\
\hline 0.40 & \#NAME? & \#NAME? & \#NAME? \\
\hline 0.45 & \#NAME? & \#NAME? & \#NAME? \\
\hline 0.50 & \#NAME? & \#NAME? & \#NAME? \\
\hline 0.55 & \#NAME? & \#NAME? & \#NAME? \\
\hline 0.60 & \#NAME? & \#NAME? & \#NAME? \\
\hline 0.65 & \#NAME? & \#NAME? & \#NAME? \\
\hline 0.70 & \#NAME? & \#NAME? & \#NAME? \\
\hline 0.75 & \#NAME? & \#NAME? & \#NAME? \\
\hline 0.80 & \#NAME? & \#NAME? & \#NAME? \\
\hline 0.85 & \#NAME? & \#NAME? & \#NAME? \\
\hline 0.90 & \#NAME? & \#NAME? & \#NAME? \\
\hline 0.95 & \#NAME? & \#NAME? & \#NAME? \\
\hline
\end{tabular}

Risked Liquids in Gas Accumulation

\#NAME?

\begin{tabular}{|c|c|c|c|}
\hline Fractile & Sweet Spots & "Non-Sweet Spots & "Total AU \\
\hline 0.05 & \#NAME? & \#NAME? & \#NAME? \\
\hline 0.10 & \#NAME? & \#NAME? & \#NAME? \\
\hline 0.15 & \#NAME? & \#NAME? & \#NAME? \\
\hline 0.20 & \#NAME? & \#NAME? & \#NAME? \\
\hline 0.25 & \#NAME? & \#NAME? & \#NAME? \\
\hline 0.30 & \#NAME? & \#NAME? & \#NAME? \\
\hline 0.35 & \#NAME? & \#NAME? & \#NAME? \\
\hline 0.40 & \#NAME? & \#NAME? & \#NAME? \\
\hline 0.45 & \#NAME? & \#NAME? & \#NAME? \\
\hline 0.50 & \#NAME? & \#NAME? & \#NAME? \\
\hline 0.55 & \#NAME? & \#NAME? & \#NAME? \\
\hline 0.60 & \#NAME? & \#NAME? & \#NAME? \\
\hline 0.65 & \#NAME? & \#NAME? & \#NAME? \\
\hline 0.70 & \#NAME? & \#NAME? & \#NAME? \\
\hline 0.75 & \#NAME? & \#NAME? & \#NAME? \\
\hline 0.80 & \#NAME? & \#NAME? & \#NAME? \\
\hline 0.85 & \#NAME? & \#NAME? & \#NAME? \\
\hline 0.90 & \#NAME? & \#NAME? & \#NAME? \\
\hline 0.95 & \#NAME? & \#NAME? & \#NAME? \\
\hline
\end{tabular}


USGS 2010 Continuous Methodology

version 2.0 - August 29, 2011

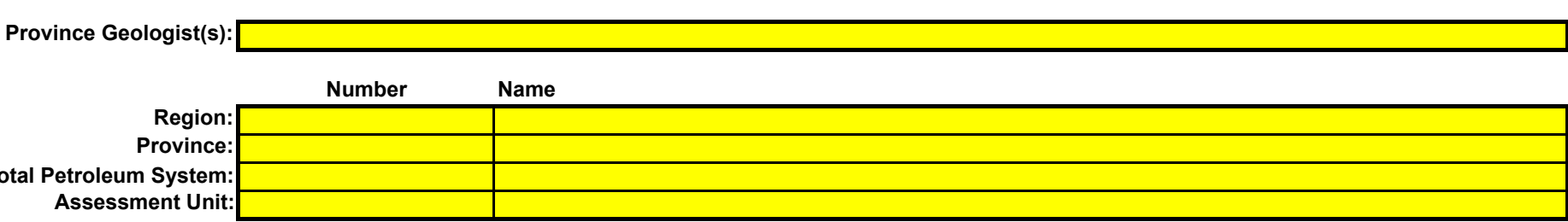

Date:

Oil or Gas?

Petroleum System:
Assessment Unit

Oilor Gas?

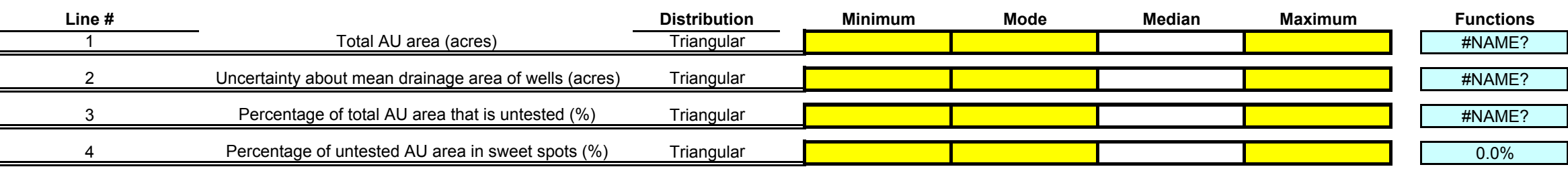

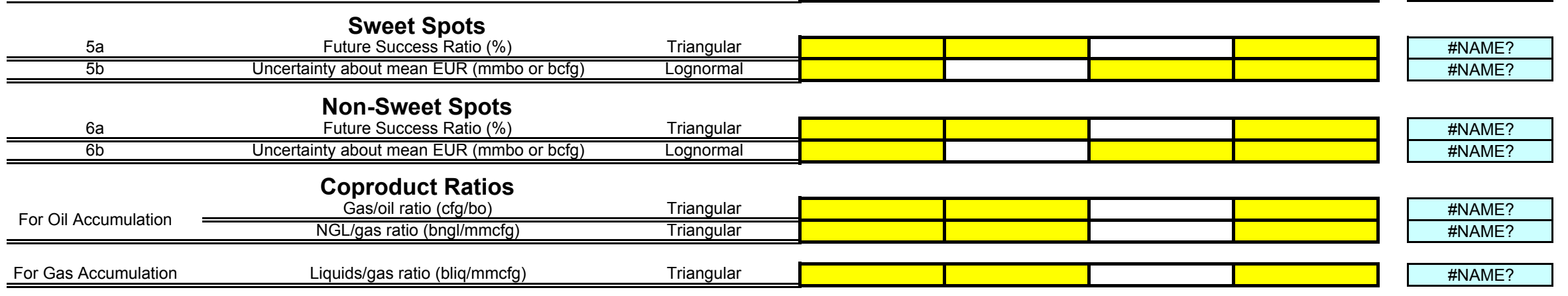

AU Probability $\square$

Correlation $\quad 0.50$ 
Publishing support provided by:

Denver Publishing Service Center

For more information concerning this publication, contact: Center Director, USGS Central Energy Resources Science Center Box 25046, Mail Stop 939

Denver, CO 80225

(303) 236-1647

Or visit the Central Energy Resources Science Center Web site at: http://energy.cr.usgs.gov/ 
